Portland State University

PDXScholar

\title{
Late-Night Political Comedy's Impact on Audience Political Attentiveness, Public Opinion, and Civic Engagement
}

Molly J. Olmstead

Portland State University

Follow this and additional works at: https://pdxscholar.library.pdx.edu/honorstheses

Part of the Communication Commons, Politics and Social Change Commons, and the Television Commons

Let us know how access to this document benefits you.

\section{Recommended Citation}

Olmstead, Molly J., "Late-Night Political Comedy's Impact on Audience Political Attentiveness, Public Opinion, and Civic Engagement" (2020). University Honors Theses. Paper 986.

https://doi.org/10.15760/honors.1010

This Thesis is brought to you for free and open access. It has been accepted for inclusion in University Honors Theses by an authorized administrator of PDXScholar. Please contact us if we can make this document more accessible: pdxscholar@pdx.edu. 


\title{
Late-Night Political Comedy’s Impact
}

on Audience Political Attentiveness, Public Opinion, and Civic Engagement

\author{
by \\ Molly Olmstead
}

An undergraduate honors thesis submitted in partial fulfillment of the requirements for the degree of

Bachelor of Arts

in

University Honors

and

Communication

Thesis Adviser

Tanner Cooke

Portland State University

2020

Abstract 


\section{How does late-night political comedy impact audience political attentiveness, and public opinion, specifically focusing on knowledge about politics and civic engagement?}

This thesis examines the relationship between late-night comedy news shows and their audiences, in terms of how they impact public opinion, political attentiveness and civic engagement. It looks at how the genre of late night political comedy is not a monolith, and neither is its audiences, and addresses the different ways these two interact with one another. Through an in-depth literature review, this thesis finds that late night political comedy has the most impact on politically inattentive audiences who end up learning about politics inadvertently, and that the jokes featured on these shows actively primes these viewers to hold certain views on political candidates and systems. The research points to key communication and humor theories that help explain these findings.

Intro 
In 2005, Stephen Colbert made headlines when he coined the phrase "truthiness" during a late-night monologue on The Colbert Report. The phrase was in regards to United States President George W. Bush's statements on nominating Harriet Miers to the Supreme Court- in which he used the phrase, "I know her heart" to support his decision. Colbert used his typical satirical humor to follow the thread of what a society looks like when we place feelings over fact, making the joke that, "Books are elitist. Constantly telling us what is or isn't true or what did or didn't happen.” (Colbert et. al, 2005). This 'word of the day' found its way from a joke told as a late-night bit to being validated by the American Dialect Society as their word of the year. The New York Times highlighted it as one of the words that 'captured the spirit of 2005', and in 2006 it was Merriam-Webster's 'Word of the Year', beating out the word 'google” by a wide margin.

We construct our world through the language we use. The words we use mean something, so when Colbert created a word that was then validated by the dictionary, we can directly see the impact that late-night political comedy has on the world around us and on public opinion. This one joke was heard around the world, formed the basis of countless social and political commentaries, and became so widespread in its critique of our government valuing opinions over fact, and became a stepping stone to what we now call "fake news". All this came from one television show's comedic routine remarking on the President's wording, singling out a much larger problem in our value system.

What this highlights is how pervasive late-night political comedy is in our society, the reach and impact it has on public opinion, and the significance of these commentaries on real systemic and institutional structures. If a single two-minute bit has the power to be marked permanently significant by the Merriam-Webster Dictionary, what impact does an entire episode 
have? An entire season? What about other late-night political comedy acts? What is not within the reach of this media form?

As comedic news media continues to proliferate on television and has found new avenues of distribution via online streaming, its power and influence must be reassessed. Specifically, in this age of fake news, divisive politics, and polarized voters, it's important to understand late night political comedy's impact on political communication and public opinion. Studying late-night political comedy has the potential to shed light on what influences public opinion and what motivates people to action. What we consume creates our worldview, and influences the way we interact with our environment. Thus, this thesis is driven by the following research questions:

RQ1: How does late-night political comedy impact public opinion?

RQ:2 How does late night comedy impact political attentiveness?

RQ:3 How does late night political comedy impact civic engagement?

To address these questions, this research will be conducted through a detailed literature review. The literature used for this review consists of academic journal articles focusing on: late night comedy, humor, and political communication. Importantly, it is not only academic literature that has engaged with late night political comedy. As such, this review also considers material produced by political think tanks and media watchdog organizations.

\section{Humor}

The heart of this study is ultimately humor. Although the focus is on late night political comedy, it is first important to lay out how humor as a form of communication, specifically satire, significantly interacts with how we deal with and interpret a message. Satire as a form of humor is tricky due to its ambiguous nature. When humor is purposefully ambiguous, audiences 
look for external cues to signal them to shift frames (Baym 2005; Young \& Tisinger, 2006; Young, 2008). Hovland \& Weiss's (1951) learning theory demonstrates that when external cues are not given, which is frequently found in satire and deadpan humor, an audience member begins to turn to internal cues. When an individual is distracted, has low comprehension, or holds internal motivations, unbiased message processing becomes very difficult. This is where they engage in biased processing that favors their own previously held beliefs.

When external cues are not present, audience members are forced to do more cognitive work to discern not only if the source is using humor, but whether or not the underlying message is sincere or not. When we consume entertainment media our motivation to perform high cognitive work is significantly lowered, which means that when faced with the job of figuring out what Colbert is really saying on his show, we tend to take the easier and biased peripheral route, rather than the thoughtful central route to reach a conclusion.

The Elaboration Likelihood Model (Petty \& Cacioppo, 1980) can help us understand how much cognitive effort a person will perform when engaging with a message. This dual-process model lays out influences and motivations that send people down one of two routes when faced with an issue. The first is the central route, which refers to how someone interacts with a message when the motivation for elaboration is high- this might look like thoughtfully engaging with and examining the issue at hand. In comparison, the second route, the peripheral route, is used when the motivation for elaboration is low, and the reader falls back on peripheral or less relevant cues, such as how the individual feels about the sender of the message, to establish an attitude or belief about the issue.

The factors that influence the motivation for or the ability to seek elaboration include the relevance of the topic, the receiver's level of enjoyment in thinking, and the level of distraction. 
Each of these factors can motivate or make it difficult for readers to critically engage with a topic. Distraction comes into play when looking at how audiences engage with entertainment programs, because the humor tends to distract audiences from choosing to seek elaboration on the messages being transmitted in an entertainment format. This encourages audiences to take the peripheral route, and determine their stance on issues using cues like how trustworthy or attractive they deem the sender. To receive political information in a humorous frame means that many viewers who are prompted to take the peripheral route don't critically engage with the material and instead are making up their minds on these topics using non-relevant cues. In all, it's important to look at humorous content separately from 'hard news', because we process it completely differently, yet it still holds a privileged position as part of our news mediascape.

\section{Late Night Political Comedy}

Political humor has existed for centuries, with some scholars tracing the practice back to Ben Franklin or Mark Twain (Whitfield, 1988), and it has only gained popularity as media organizations have found value in producing political comedy, and as audiences continue to rely on political comedy to make sense of the complex political worlds that we live in. Political humor uses parody and satire to poke fun at politicians and the government, and acts as the basis for late night political comedy. Scholars designate late-night comedy news into the category of 'soft news', which they define as “programs featuring lower levels of public affairs information and focusing more on drama, sensationalism, human interest themes, and personalities." (Baumgartner, 2006, p. 341), and make the distinction that, "While traditional news programs report the news in order to inform the audience, at least in some significant measure, the soft news media seek almost exclusively to entertain the audience." (Baum, 2003). This is most clearly illustrated in the use of comedians and well known pop culture icons as soft news hosts, 
while hard news shows opt for journalists.

For the purpose of this thesis, late-night political comedy will be defined as media that features a host discussing current social and political news in a comedic and humorous way, often mimicking the set up of 'hard news' shows (Baek \& Wojcieszak, 2009). This can exist in the form of parodying other news hosts- as seen with The Colbert Report, or as just a show geared toward social and political comedic commentary without this parody element, as seen with The Daily Show with Jon Stewart.

Baumgartner (2008) addresses the common idea held by previous scholarship that the audience of late-night political comedy is "monolithic" or homogenous, as well as that late-night political comedy itself, is monolithic- when in fact there are distinct differences in the people who consume this form of media, and even larger differences in the types of humor and delivery of these top hosts. These differences have a large impact on our key variables, audience attentiveness, engagement, and political attitudes and ideals. This thesis will mainly focus on The Colbert Report with Stephen Colbert, and The Daily Show with Jon Stewart, although there are a multitude out there to be studied.

The Daily Show, which premiered in 1996, is a late night political comedy show that satirizes traditional hard news programs. The host has transitioned from Craig Kilborn, to Jon Stewart, and most recently Trevor Noah. This thesis is focusing on the Jon Stewart 'era', due to the huge influence he had in terms of the show's ratings and trajectory. The show is structured as a typical news show, with news updates, fake correspondence and guest interviews. John Stewart utilizes a form of humor that puts him as a host in a position to critique outlandish political events, figures, and acts by straight out making fun of and denouncing them.

During Stewart's time at the helm, the cable show won 23 Primetime Emmy Awards and 
three Peabody Awards, had roughly 1.45-1.6 million viewers per night (Vulture, 2008), and he was named 'America's Most Trusted Newscaster' in a 2009 poll by TIME magazine (TIME, 2009). The Pew Research Center reported that " $74 \%$ of regular viewers were between 18 and 49 , and that $10 \%$ of the audience watched the show for its news headlines, $2 \%$ for in-depth reporting, and $43 \%$ for entertainment; compared with respectively $64 \%, 10 \%$ and $4 \%$ who said the same of CNN." (PEW 2010). The show has received criticism from co-host of CNN's Crossfire Tucker Carlson (Cave, 2004) and Daily Show co-creator Lizz Winstead (Kurt, 2004), for not being hard hitting enough, to which the program rebutes by reminding the public that they are an entertainment-focused show first and foremost, and not an actual news broadcast. Jon Stewart has also been known to agitate other 'hard news' show hosts through his jokes, most notably his "arch-nemesis" the conservative host of the O'Reilly Factor, and former FOX news figurehead, Bill O'Reilly. The two went head-to-head in a series of debates and charged interviews, touching on issues of race and fear-based journalism. This longstanding feud demonstrates the reach of Stewart's soft news show, and the serious manner in which hard news shows engaged with and responded to his comedy platform.

What was so monumental about Stewart's time at The Daily Show was that he changed the show's direction to encompass a sharper political focus, from focusing on harder hitting news stories, as well as encouraging correspondence to move away from 'human interest-y' pieces toward more news driven stories. We can see this in recurring segments like "Mess O' Potamia", which chronicled the war in Iraq, as well as "Indecision" \& "Democalpyse" which have covered our presidential elections since 2000. Jon Stewart's depiction of the 2004 presidential election campaign was actually found to be equally substantial to broadcast nightly newscasts such as ABC's World New Tonight with Peter Jennings, CBS's Evening News with Dan Rather, and 
NBC's The Nightly News with Tom Brokaw in a study comparing the difference in coverage (Fox, Koloen, \& Sahin, 2007). Either the Daily Show with Jon Stewart is a strong source of political information, or our trusted 'hard' news sources are less substantial than we give them credit for.

A spin-off of The Daily Show is The Colbert Report. Hosted by Steven Colbert, who got his start as a correspondent under both Craig Kilborn and Jon Stewart, The Colbert Report is equally, albeit in different ways, worth discussing. While the shows are both under the same genre they are very different, because late night comedy is not a monolith. While The Daily Show with Jon Stewart follows suit with other late night talk show hosts like Jay Leno or David Letterman, where they openly critique politicians and political systems through their jokes, Steven Colbert assumes the satirical role of a conservative news host like that of Bill O'Reilly and critiques far-right politics by aggressively supporting them in an effort to expose their fallacies. Colbert dresses and talks like a conservative news host, and makes his commentary in his satirical over the top support for conservative politics.

The Colbert Report features American motifs throughout the show, from bald eagles, to American flags, and everything on set is tinted some form of red, white, and blue. It follows a format in which Colbert opens with a monologue regarding the day's topic, moves on to recurring segments such as "The Word”, in which he parodies Bill O'reilly's "Talking Points Memo", and includes an interview or two of either fake correspondents or real political figures. Colbert himself notes that his jokes are neither attacking solely conservative or liberal politics, but instead those in power, saying "satire usually exists in opposition to power or as commentary on power", and that he uses his platform to punch up. Because of this stance, both conservatives and liberals enjoyed the show, although in their study Lamarre et al. (2009) found that while 
"there was no significant difference between the groups in thinking Colbert was funny, conservatives were more likely to report that Colbert only pretends to be joking and genuinely meant what he said while liberals were more likely to report that Colbert used satire and was not serious when offering political statements"(212).

In terms of ratings and audience demographics, The Colbert Report nearly echoed The Daily Show with Jon Stewart, with around 1.5 million views per show and a median viewer age of 39.4. In 2013, The Daily Show was the most watched late-night talk show among 18-29 year olds, followed closely by the Colbert Report (Bibel, 2013). We can see that these shows garner millions of viewers ages $18-49$, and when this many people are tuned into these two hosts it's important to look at what kind of influence they have on this large group of voters.

\section{Body:}

When looking at the impact late night political comedy has on viewers, there are three main points to assess. These are 'public opinion', 'political attentiveness', and 'civic engagement'. Assessing public opinion entails seeing how influential these shows are in determining how the public views certain topics, candidates, or politicians. Political attentiveness or awareness is looking at audience backgrounds in paying attention to politics, as well as how likely it is that watching these shows encourages them to seek out more information. And finally, attitude change is weighing the likelihood that these shows can shift attitudes on a topic.

\section{Public opinion}

Public opinion is seen as the views held by the general public, and as such, understanding public opinion allows political campaigns, authorities, and legislation to capitalize and best serve our citizens. Public opinion influences how we vote, how we react to politics, and how we engage with the world around us. Current public opinion is largely created through mass media, 
which means that it is likely that we can tell a lot about how society feels about certain issues based on how they're talked about in our media because it is both a reflection and an influencer of held beliefs. In terms of late-night political comedy, scholars believe that "these jokes probably serve as a thermometer — and possibly even a thermostat — for public opinion.” (Young, 2008, p 119).

A number of studies have evaluated the impact of audiences' exposure to the content in late-night political comedy programs. From Baum (2005), who found that less knowledgeable audiences, as well as those who are only passively interested in politics, are more likely to be influenced by candidates appearances on these late-night talk shows, especially when the candidates were humanized and given the chance to share anecdotes and friendly small talk. Baumgartner (2006) pushes the discourse further by looking at what the impact of repetitive jokes at candidates' expense have on audiences rather than just the impact of celebrity and candidate TV show appearances have. For example, what kind of impression do audiences form when seeing a talk show appearance of the candidate where policy is rarely discussed, vs when Jon Stewart roasts their politics and makes jokes at their expense repeatedly? This study finds that exposure to Jon Stewart lowers support for presidential candidates and increases cynicism of the political system. Which the study acknowledges could be good for democracy, while its ability to turn voters off from either candidate, which was not.

Political humor has been found to prime viewers in a number of ways by other researchers (Cao \& Brewer, 2008; Young 2004b, 2006). When politicians and political candidates are seen on talk shows, viewers are more likely to use specific character traits to base their candidate evaluations (Baum, 2005). In turn, while these shows are able to humanize and 
make candidates more likable, political humor can also "prime negative evaluations of presidential candidates and other political institutions.” (Baumgartner \& Morris, 2008, p 623)

In terms of changing public opinion, The Daily Show with Jon Stewart has specifically been found to lower support for presidential candidates and increase cynicism of the political system (Baumgartner, 2006). This is seen in the way that Stewart speaks negatively of all aspects of the political system, which primes his viewers, namely inexperienced and less educated voters, to believe that it's all bad. How does this impact voters in terms of turnout, engagement in civic action and our political process? In order to dive deeper into these questions we must look at the impact these shows have on how much audience members pay attention to politics, as well as how often they get involved.

\section{Political attentiveness}

In addition to looking at how late-night political comedy impacts public opinion, it's important to see how it interacts with the degree to which viewers pay attention to politics. This allows us to see how impactful a single show is on where viewers gain political information, and how invested they are in researching and learning about a topic. This can help paint a better picture of how much emphasis viewers place on learning from a variety of sources, and how likely they are to critically engage with a topic. One method of measuring the degree to which people pay attention to political messages is by looking at what scholars call 'political attentiveness'. Political attentiveness is defined by Cao (2010) as, "being able to recognize and selectively process information about a topic..."attentiveness to a political issue implies that individuals not only possess sufficient information to recognize its existence but also expose themselves to additional information about it.'(p. 30). 
What those who study late-night political comedy have come to agree upon is that these programs can impact political attentiveness and knowledge, but only in audiences with low-level political knowledge or those who are politically apathetic (Baum, 2003a; Young, 2008). This is due to the fact that these shows feel more accessible than hard news, while also including less indepth information regarding the issues being covered. That is not to mean that these programs have little to no power for change, in fact it is a strong tool to use to motivate and engage viewers who have not and might not have otherwise gotten involved in politics. John Stewart's show is able to meet politically apathetic viewers in the middle in giving entertainment and information, which Cao (2010) argues makes these viewers more likely to become politically attentive. Viewers who are not invested in politics and unmotivated to watch hard news shows "may passively and inadvertently gain political information from late-night comedy" (Baum, 2002). These soft news shows serve "as gateways to more traditional news use and contribute to an equalizing effect over time in which political engagement is no longer as strongly correlated with attentiveness to high-profile political stories" (Young \& Tisinger, 2006, p. 116). All of these points make it clear why, when trying to understand the politically unmotivated and uneducated voter demographic, it's important to have a strong sense of where they are purposefully, or inadvertently, getting their information.

\section{Civic Engagement}

Earlier we outlined how late night political comedy shows are able to both get apathetic audiences to pay attention to the political sphere, as well as prime them to make certain evaluations of candidates, now we can extend this research to look at how this impacts the political actions of viewers. When this large group of previously uninterested citizens, Jon Stewart's show alone brought in around 2 million 18-49 year olds, are suddenly gaining an 
interest in politics, where they begin to form their political opinions will hold the most weight in the votes they cast. The ideal voter is tuning into multiple sources to gain information with which they'll critically engage with in order to come to their own conclusion on an issue, this creates well rounded and engaged citizens. As laid out by ELM theory, when we consume humor messages, especially ones that are tricky to understand like satire, we mentally choose to not engage critically with the message and instead use peripheral processing, such as taking into account their mood, general impressions, and early parts of the message in order to make up their minds on a subject. So what does this mean when humor messages are what spur individuals to action? How does this impact how they take part in our democracy?

In a study conducted by Stewart (2007), it was found that in addition to creating distrust of politicians, late night political comedy increased viewers' active and passive participation in politics. Active participation was defined as when "a person attempts to influence government policy and the selection of candidates, which includes behaviors such as registering to vote, voting, working for a political campaign, seeking elective office and writing letters to the editor about policy matters.”(Conway, 2000, as cited in Stewart, 2007, p. 6)., while passive participation includes activities such as paying attention or attending civic events. The study countered previous scholars who have claimed that the Daily Show's role in creating lowered trust in the government was a negative trait, by coupling this fact with data showing that it doesn't turn viewers away from engaging with the political process, instead it turn them into citizens with "healthy skepticism" that aids our democracy (Schudson, 1999).

\section{Discussion}

We can now return to our research questions after having examined the literature. In terms of how late-night political comedy impacts public opinion (RQ1), we have found that these 
programs are able to prime viewers to make judgements about political figures, candidates, and policies through joking, humanizing these figures, and repetition. The Daily Show was found to encourage a distrust of the political system, while the Colbert Report made viewers feel like they understood politics and that it supported their current views. Clearly there is power to influence the minds of viewers, especially when these viewers were shown to be relatively young and politically inattentive.

This leads into our second research question, how does late night comedy impact political attentiveness (RQ:2). While a portion of these viewers were described as politically inattentive or unmotivated, the data demonstrated that these shows served as a gateway to more 'hard news' programming, and that the difference between these and 'actual news shows' is not as stark as one might expect (Fox, Koloen, \& Sahin, 2007). The Daily Show and The Colbert Report are both able to reach unmotivated viewers by having them passively attain political information, whereas without the entertainment format they might not have.

Finally, research question 3 asks, how does late night political comedy impact civic engagement? The literature tells a story of previously inattentive viewers both gaining political information through this humorous format as well as feeling encouraged to take this newfound interest to engage in political systems both passively and actively, most notably by voting. We can answer RQ:3 by stating that late night political comedy impacts viewers' civic engagement by encouraging them to get involved in politics in multiple ways, most notably through voting.

\section{Conclusion}

As we find answers for our three research questions through literature analysis and review, we are able to broaden the application of these facts and use them to understand further how media influences the way we interact with politics. The methods in which we consume 
political messages is changing rapidly, and if we are unable to pay attention to and understand the different ways they impact us, we lose the ability to predict how large swaths of voters will act based on the influences of a select few.

Knowing the influence of these shows can allow us to better educate voters, strengthen campaign strategies, and understand voting patterns. As we move from disregarding these programs as simply entertainment, and begin recognizing the cultural and political significance they hold in our country, we can pay closer attention to the topics they bring attention to and the influence they have on our public. We must also think about the implications of these entertainment media forms having a similar audience, similar influence, and similar amount of substance as typically hard news broadcasts. As more people turn toward The Daily Show or The Colbert Report and are receiving large portions of their political knowledge from these shows, we must wonder what our media is turning into and what we want it to be. We must look at why people are turning away from traditional news sources, why these late-night comedy shows are so appealing to the masses, why we have so much trouble distinguishing them from hard news. Has our hard news become as sensational as late-night comedy? In a interview of Jon Stewart by Bill Moyers we can see the blend of entertainment and news bleeds into both sides of the spectrum, with groups claiming Jon Stewart is more of a journalist than he lets on, and studies like Fox, Koloen, \& Sahin (2007) that show that these traditional hard news shows we compare him to aren't actually any more substantial than their parodies:

MOYERS: I do not know whether you are practicing an old form of parody and satire. STEWART: Uh-huh. MOYERS: Or a new form of journalism. 
STEWART: Well then that either speaks to the sad state of comedy or the sad state of news. I can't figure out which one. I think, honestly, we're practicing a new form of desperation. Where we just are so inundated with mixed messages from the media and from politicians that we're just trying to sort it out for ourselves.

Essentially, after evaluating the influence these late night comedy news shows have on our public in terms of attitude change, public opinion, and civic engagement, we must now look at what these means in terms of the direction political news is headed in the future, as well as the current state of 'hard' news programs. As this genre of programming gains popularity and traction, they gain recognition from credible media, such as Merriam Webster's dictionary, TIME magazine, and hard news broadcasts like The O'Reilly Factor and Crossfire.

The fact that these entertainment based shows have such an influence on the American public, as seen in their recognition from credible media, such as Merriam Webster's dictionary, TIME magazine, and hard news broadcasts like The O'Reilly Factor and Crossfire, as well as the millions of viewers who uses this show to form their political opinions, we can see that the political media field is shifting and we need to pay attention. This shift to both further politicize comedic programming, and the sensationalization of traditional news leaves the public in uncharted territory.

Further research needs to look into the way that late night political comedy and traditional hard news are beginning to blend together, and what impact this might have on how our nation seeks out and consumes political media, and how the shift might impact voters, and as a consequence, our democracy. 


\section{References}

Baek, Y. M., \& Wojcieszak, M. E. (2009). Don’t expect too much! Learning from late-night comedy and knowledge item difficulty. Communication Research, 36(6), 783-809. https://doi.org/10.1177/0093650209346805

Baum, M. A. (2002). Sex, lies, and war: How soft news brings foreign policy to the inattentive public. American Political Science Review, 96, 91-109.

Baum, M. A. (2003). Soft news and political knowledge: Evidence of absence or absence of evidence? Political Communication, 20(2), 173-190. doi:10.1080/10584600390211181

Baum, M. A. (2005). Talking the vote: Why presidential candidates hit the talk show circuit. American Journal of Political Science, 49, 213-234

Baumgartner, J. (2006). The Daily Show effect: Candidate evaluations, efficacy, and American youth. American Politics Research, 34(3), 341-367.

Baumgartner, J., \& Morris, J. S. (2006). The Daily Show Effect: Candidate evaluations, efficacy, and american youth. American Politics Research, 34(3), 341-367. https://doi.org/10.1177/1532673X05280074

Baumgartner, J. C., \& Morris, J. S. (2008). One "nation," under Stephen? The effects of The Colbert Report on American youth. Journal of Broadcasting \& Electronic Media, 52(4), 622-. Retrieved from https://link-gale-com.proxy.lib.pdx.edu/apps/doc/A192586872/PPCM?u=s118578 $4 \& \operatorname{sid}=$ PPCM\&xid=12b06684

Baym, G. (2005) The Daily Show: Discursive integration and the reinvention of political journalism, Political Communication, 22:3, 259-276, DOI: 10.1080/10584600591006492 Bibel, Sara (April 4, 2013). "'The Daily Show' and 'The Colbert Report' finish first quarter 
2013 as number 1 and number 2 among adults 18-49". Zap2it.

Cao, X. \& Brewer, P. (2008). Political comedy shows and public participation in politics. International Journal of Public Opinion Research. 20. 10.1093/ijpor/edm030. Cao, X. (2010). Hearing it from Jon Stewart: The impact of the Daily Show on public attentiveness to politics. International Journal of Public Opinion Research, 22(1), 26-46. doi:10.1093/ijpor/edp043

Cave, D. (October 24, 2004). "Jon Stewart gets serious: If you interview Kissinger, are you still a comedian?". The New York Times. ISSN 1553-8095. OCLC 1645522. Archived from the original on April 13, 2016. Retrieved July 5, 2008. Colbert, S., Stewart, J., Purcell T. (Producer). (2005, October 17). The Colbert Report [Television broadcast]. New York, NY: Comedy Central

Fox, J. R., Koloen, G., \& Sahin, V. (2007). No joke: A comparison of substance in The Daily Show with Jon Stewart and broadcast network television coverage of the 2004 presidential election campaign. Journal of Broadcasting \& Electronic Media, 51(2), 213-227. doi:10.1080/08838150701304621

Hovland, C. I., \& Weiss, W. (1951). The Influence of source credibility on communication effectiveness. Public Opinion Quarterly, 15(4), 635. doi:10.1086/266350

Kurt, A. (2004). "Taking back the dial". Mother Jones (May/June 2004). ISSN 0362-8841. Archived from the original on January 5, 2018. Retrieved July 4, 2008.

LaMarre, H. L., Landreville, K. D., \& Beam, M. A. (2009). The irony of satire. The International Journal of Press/Politics, 14(2), 212-231. doi:10.1177/1940161208330904 
Petty, R. E., \& Cacioppo, J. T. (1986). The elaboration likelihood model of persuasion. Advances in Experimental Social Psychology, 123-205. doi:10.1016/s00652601(08)60214-2

PEW (September 12, 2010). "Americans spending more time watching the news". Pew Research Center.https://www.pewresearch.org/politics/2010/09/12/americans-spendingmore-time-following-the-news/

Stewart, D. (2007) 'The Daily Show Effect' revisited: How satire contributes to political participation and trust in young audiences (July 27, 2007). Paper Presented in the Entertainment Studies Interest Group at the AEJMC 2007 Annual Conference in Washington, D.C., Available at SSRN: https://ssrn.com/abstract=3130227 or http://dx.doi.org/10.2139/ssrn.3130227

Schudson, M. (1999). The good citizen: A history of American civic life. Cambridge, MA: Harvard University Press.

Time (2009). "Now that Walter Cronkite has passed on, who is America's most trusted newscaster?". Time. ISSN 0040-781X. OCLC 1311479. Archived from the original on July 24, 2009. Retrieved November 20, 2010.

Vulture, (2008)."Jon Stewart's Nielsen Ratings Down 15 Percent; Colbert's Up 11 Percent". New York. January 2008. Retrieved March 23, 2008.

Whitfield, S.J. (1988). Political Humor, in Mintz, L.E. (ed.), Humor in America, 195212.. New York: Greenwood Press.

Young, D. G. (2004, September). The counterargument-disruption model of political humor 
(CADIMO): An experimental exploration of the effects of late-night political jokes on cognitive elaboration and the conditional effects of partisanship. Paper presented at the annual meeting of the American Political Science Association, Chicago.

Young, D. G. (2008). The privileged role of the late-night joke: Exploring humor's role in disrupting argument scrutiny. Media Psychology 11(1),119-142.

Young, D. G., \& Tisinger, R. M. (2006). Dispelling Late-Night Myths. Harvard International Journal of Press/Politics, 11(3), 113-134. doi:10.1177/1081180x05286042 